\title{
Recovery of Globba wengeri (C.E.C. Fisch.) K.J. Williams, critically endangered plant species from Serchhip District in Mizoram, Northeast India
}

\author{
Lalnunmawia, Vanlalhruaii Ralte*, H. Lalruatsanga, Zothanmawia, P.C. Vanlalhluna, H.S. Thapa \& \\ R. Vanlalpeka \\ Department of Botany, Pachhunga University College, Aizawl 796 001, India \\ *Email: apuii_r@yahoo.com
}

\section{ARTICLE HISTORY}

Received: 04 December 2019

Accepted: 26 January 2020

Published: 01 April 2020

KEYWORDS

Globba wengeri; dancing girl; rare and endemic; Mizoram
ABSTRACT

Globba wengeri (C.E.C. Fisch.) K.J. Williams, former state flower of Mizoram, a rare and critically endangered plant species, commonly known as 'dancing girl', belonging to the family Zingiberaceae, is reported in this communication for the first time from Serchhip District in Mizoram at an elevation of about $1187 \mathrm{~m}$ a.s.l. It was found on moist, watery and rocky slopes. The plant is under severe threat in the natural habitat and therefore, further studies are required to determine life history and particular survival threats of this species.

\section{Introduction}

The family Zingiberaceae consists of about 50 genera and a total number of about 1600 known species (1). In India, around 200 species belonging to 20 genera of Zingiberaceae are reported so far (2). The four species of Globba L. such as Globba spathulata Roxb., Globba radicalis Roxb., Globba wengeri (C.E.C. Fisch.) K.J. Williams and Globba wardii (B.L.Burtt \& R.M.Sm.) K.J.Williams were found endemic to the hilly areas of North East India and Myanmar (3). In addition, a new species specifically called Globba salarkhanii (M.A. Rahman \& Yusuf) Govaerts was described from Bangladesh (4). Globba wengeri (C.E.C. Fisch.) K.J. Williams is a highly fascinating plant species belonging to the family Zingiberaceae and is commonly known as 'dancing girl' because the yellow corolla looks like a skirt and the two staminodes resemble the two outstretched arms of a dancing girl (5). It is thought to be a hybrid of $G$. spathulata Roxb. and G. radicalis Roxb. (3).

G. wengeri had been listed in the Red Data Sheet of rare and endangered Indian plants due to its extreme rarity and small population in its natural habitat and hence included in the national priority list for species recovery by the Department of Biotechnology, Govt. of India (6). The species is found endemic to Mizoram, Northeast India (https://indiabiodiversity.org/observation/show/309257). The plant population has declined in their natural habitat and latest report was from Lunglei District in Mizoram (7). And there has been no report from another location in the state. It was reported that the rhizome of this species was used as a remedy for bone fractures and gastrointestinal ailments (5). G. wengeri was the state flower of Mizoram till 2009 but because of its extreme rarity it was now replaced by Renanthera imschootiana Rolfe (Orchidaceae).

The plant species was accidentally found in the month of May, 2018 by the Adventure Club of Pachhunga University College while visiting Khawhthlasang waterfall $\left(23^{\circ} 03^{\prime} 28^{\prime \prime} \mathrm{N}\right.$ latitude and 9302'22” E longitude, alt. $1187 \mathrm{~m}$ above msl.), Tuiphai river, in the area of Maicham Small Hydel Project, North Vanlaiphai, Serchhip District, Mizoram (Photo plate 1) and the collected specimens were

(c) Lalnunmawia et al. (2020). This is an open-access article distributed under the terms of the Creative Commons Attribution License, which permits unrestricted use, distribution, and reproduction in any medium, provided the original author and source are credited (https://creativecommons.org/licenses/by/4.0/).

To cite this article: Lalnunmawia, Ralte V, Lalruatsanga H, Zothanmawia, Vanlalhluna PC, Thapa HS, Vanlalpeka R. Recovery of Globba wengeri (C.E.C. Fisch.) K.J. Williams, critically endangered plant species from Serchhip District in Mizoram, Northeast India. Plant Science Today. 2020;7(2):178-181. https://doi.org/10.14719/pst.2020.7.2.700 
thought to be an orchid species at that time. Then, field survey was carried out in the month of May, 2019 and found the species at the same location. The photographs were taken in its natural habitat and associated plants were recorded. Measurement of both the vegetative and reproductive part was also documented. The plant was identified by consulting available literature $(8,9)$. The plant population density was studied by quadrat method $\left(1 \mathrm{~m}^{2}\right)$ (10) and a total of 19 plots were laid for both adult (with flowers) and juvenile (without flowers) individuals. The whole plant was collected, some of them were pressed, air dried, mounted on the herbarium sheet $(11,12)$ and lodged in the Department of Botany,
$0.5 \mathrm{~cm}$ to $0.7 \times 1.4 \mathrm{~cm}$, ovate, pale green; flowers pedicellate, corolla yellow, tubular at base, deeply lobed, 2-lobed broader petals on the front and 3lobed smaller petals behind, corolla tube slender, curved and villous; filament slender, hairy; labellum is cordate and deeply lobed; staminodes two in numbers, pale yellow; capsules green.

Specimen Examined: India, Mizoram, Serchhip District, North Vanlaiphai, $\left(23^{\circ} 03^{\prime} 28^{\prime}\right.$ N $\mathrm{N}$ latitude and 9302’22” E longitude, alt. $1187 \mathrm{~m}$ above msl.), 14. 05. 2019, Lalnunmawia 003 (PUC).

Flowering Season: May - June.

Distribution: Endemic to Mizoram, North East India.

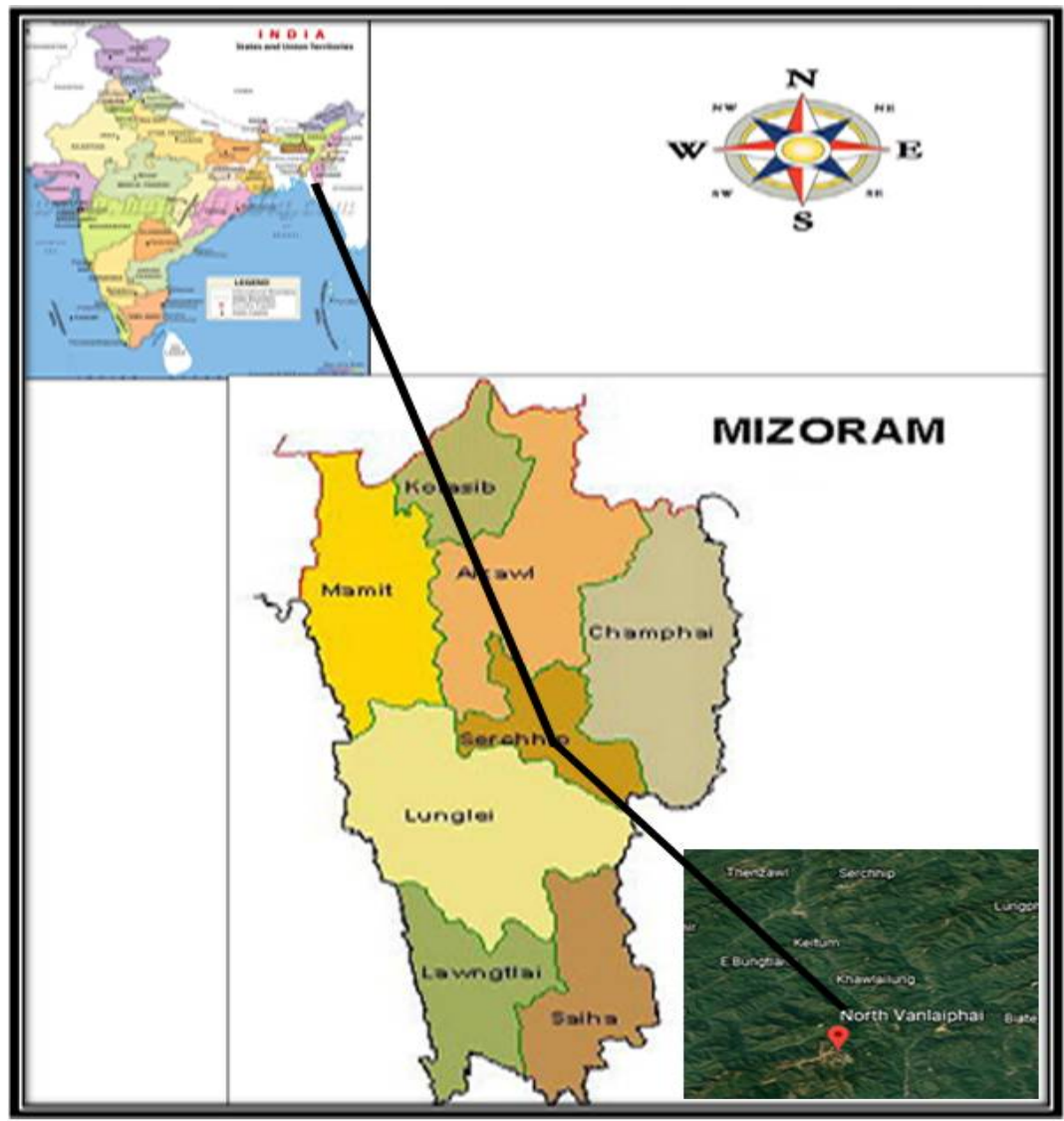

Photo plate 1. Map showing the location of the study site

Pachhunga University College (PUC), Aizawl, Mizoram. Also some of the plants were reintroduced in the pot containing forest soil collected from the college campus.

\section{Taxonomic Treatment}

\section{Globba wengeri (C.E.C. Fisch.) K.J. Williams}

Globba wengeri (C.E.C. Fisch.) K.J. Williams; Bhowmik et al., 2009, Mizoram, Lunglei District $\left(23^{\circ} 52^{\prime} 30^{\prime \prime} \mathrm{N}\right.$ latitude, $92^{\circ} 45^{\prime} 30^{\prime \prime} \mathrm{E}$ longitude, alt. $1395 \mathrm{~m}$ above msl); Vernacular Name (Mizo): Aithing/Ai-ting (Photo plate 2).

Perennial herbs; rhizomes creeping, branched, cylindrical; stems erect, unbranched; leaves approximately $2.5 \times 7 \mathrm{~cm}$ to $3.5 \times 17 \mathrm{~cm}$ in size, base sheathing, alternate, green, ovate to lanceolate, acute apex, margins no teeth, leaf blade glabrous; inflorescence upright, $10-15 \mathrm{~cm}$ long, panicles arose from the rhizome, pale green, tubular; bracts $0.3 \mathrm{x}$
Uses: Ornamental, medicinal purposes.

\section{Ecology and Conservation Notes}

The species were found in association with certain plant species like Oplismenus Beauv., Adiantum lunulatum Burm.f., moss etc, and Oplismenus sp. dominated other plants. $G$. wengeri were found growing both in groups with the same species and singly as well. It was observed that the inflorescence (reproductive part) appeared first from the dormant rhizhomes which was later followed by the vegetative shoots. Flowering usually starts during early monsoon season (i.e. May) and degenerates at the end of June.

A total number of about 298 adult and 21 juvenile individuals were recorded during the study period from 19 plots of $1 \mathrm{~m}^{2}$ quadrat. The average density for adult population was 15.68 individuals per plot. The size of the patch where the plants were 


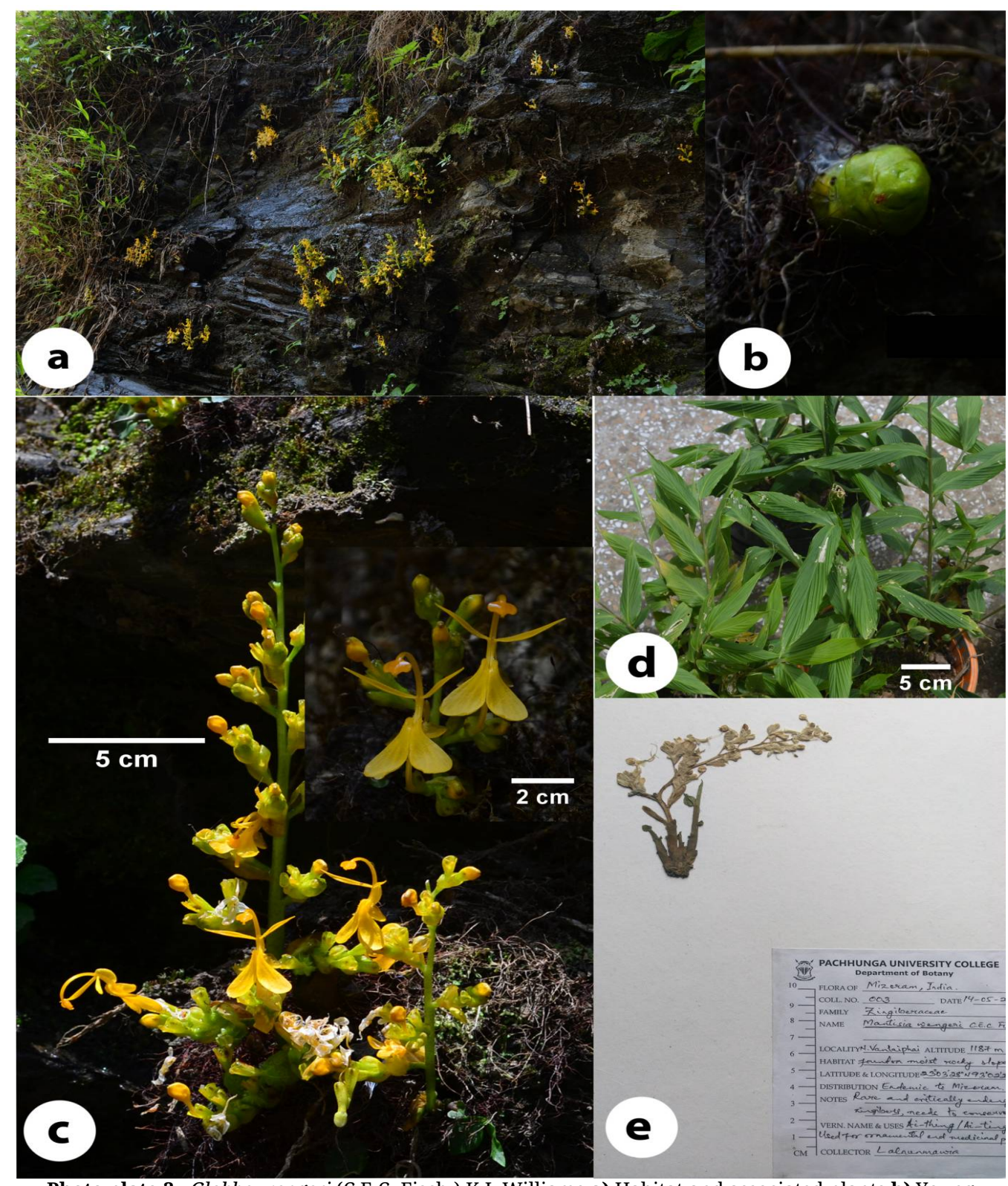

Photo plate 2. Globba wengeri (C.E.C. Fisch.) K.J. Williams a) Habitat and associated plants b) Young reproductive shoot c) Inflorescence d) Vegetative shoot e) Herbarium specimen.

found was approximately $10-13 \mathrm{~m}$ in length and 2-3 $\mathrm{m}$ in wide.

Globba wengeri is found to be extremely rare in the hilly state of Mizoram and further studies are required to determine life history and particular survival threats of this species. Therefore, an immediate conservative measures needs to be taken and it is suggested to carry out micropropagation technique for the multiplication and reintroduction of the species in the natural habitat.

\section{Acknowledgements}

The authors are grateful to Dr. Tawnenga, Principal of Pachhunga University College for his encouragement and providing financial support to carry out this research work. The assistance and cooperation of Mrs. ZD Lalremthangi is also greatly acknowledged.

\section{Competing Interests}

The authors declared that they have no competing interests.

\section{Authors' contributions}

All the authors have equally contributed to the work presented in this paper.

\section{References}

1. Govaerts R, Newman N, Lock JM. World Checklist of Zingiberaceae. Facilitated by the Royal Botanic Gardens, Kew. Published on the Internet; 2017. http://apps.kew.org/wcsp/, Retrieved on 12 June 2017

2. Kumar KMP, Asish GR, Sabu M, Balachandran I. Significance of gingers (Zingiberaceae) in Indian system of medicine Ayurveda: an overview. Anc Sci Life. 2013;32(4):253-61. http://doi.org/10.4103/0257-7941.131989 
3. Dam DP, Dam N, Dutta RM. Mantisia saltatoria Sims. versus Globba radicalis Roxb. (Zingiberaceae). Bulletin of the Botanical Survey of India. 1997;34:188-93

4. Rahman MA, Yusuf M. Mantisia salarkhani Rahman and Yusuf (Zingiberaceae) - A New Species from Bangladesh. Saudi J Biol Sci. 2002;9:105-10

5. Bhowmik SSD, Kumaria S, Tandon P. Rhizome derived callogenic plantlet production of Mantisia wengeri (Zingiberaceae), a rare and endemic medicinal plant of Mizoram, North-East India. Int Res J Biotechnol. 2010;1:65-70

6. Ganeshaiah KN. Recovery of endangered and threatened species, developing a national priority list of plants and insects. Curr Sci. 2005;89:599-600

7. Bhowmik SSD, Kumaria S, Rao SR, Tandon P. High frequency plantlet regeneration from rhizomatous buds in Mantisia spathulata Schult. and Mantisia wengeri Fischer and analysis of genetic uniformity using RAPD markers. Indian J Exp Biol. 2009;47(2):140-46
8. Williams KJ, Kress WJ, Manos PS. The phylogeny, evolution, and classification of the genus Globba and tribe Globbeae (Zingiberaceae): Appendages do matter. Am J Bot. 2004;91(1):100-14. https://doi.org/10.3732/ajb.91.1.100

9. Bhowmik SSD. Micropropagation and conservation of critically endangered Mantisia spathulata Schult. and Mantisia wenger Fischer (Zingiberaceae) of North-East India. $\mathrm{Ph} \mathrm{D}$ [Dissertation]. Shillong: North Eastern Hill University; 2009. Available from: http://dspace.nehu.ac.in/ispui/handle/1/5126

10. De A, Reang D. New locality records of the 'Dancing Girl' of Mizoram, a rare Zingiber species. J Threat Taxa. 2016;8(5):8841-43; https://doi.org/10.11609/jott.2051.8.5.8841 8843

11. Jain SK, Rao RR. A Handbook of Field and Herbarium Methods. Today \& Tomorrow's Printers and Publishers; 1977

12. Forman HL, Bridson D. The Herbarium Handbook. Kew: Royal Botanical Garden; 1989 